\title{
Electrocatalytic reduction of ROOH by iron porphyrins.
}

James P. Collman*, Marina Kaplun, Christopher J. Sunderland, and Roman Boulatov. Supporting Information.

\section{EXPERIMENTAL.}

Materials. The synthesis of the catalysts was reported elsewhere [J.P. Collman, C.J. Sunderland, R. Boulatov, Inorg. Chem. 41 (2002) 2282 (Fe(Ac), Fe(NMe)); H. Abu-Soud, J. Silver, Inorg. Chim. Acta 153 (1988) 139 (Fe(tpp)Cl)]. Peracetic acid (Aldrich, 32\%), m-chloroperbenzoic acid (Eastman Kodak), tert-butyl hydroperoxide (Aldrich, 98\%), and potassium peroxomonosulfate (Acros, 4.5\% of active oxygen) were used as supplied. $\mathrm{KPF}_{6}$ (Matrix Scientific) and $\mathrm{KNO}_{3}$ (Acros) were recrystallized. The buffers employed (Microessential Lab., N.Y.) are (0.1M): $\mathrm{KC}_{8} \mathrm{H}_{5} \mathrm{O}_{4}, \mathrm{pH}=4 ; \mathrm{Na}_{2} \mathrm{HPO}_{4} / \mathrm{KC}_{8} \mathrm{H}_{5} \mathrm{O}_{4}, \mathrm{pH}=5 ; \mathrm{Na}_{2} \mathrm{HPO}_{4} / \mathrm{KH}_{2} \mathrm{PO}_{4}, \mathrm{pH}=6,7,8$; $\mathrm{Na}_{2} \mathrm{CO}_{3} / \mathrm{NaHCO}_{3}, \mathrm{pH}=9 ; \mathrm{Na}_{3} \mathrm{PO}_{4} / \mathrm{NaHCO}_{3}, \mathrm{pH}=10,11 ; \mathrm{Na}_{3} \mathrm{PO}_{4} / \mathrm{Na}_{2} \mathrm{HPO}_{4}, \mathrm{pH} 12$.

The nature of supporting electrolyte $\left(\mathrm{KPF}_{6}, \mathrm{KNO}_{3}\right.$, or buffer only) did not affect electrochemical properties of the catalysts. All solutions were prepared immediately before use. An aliquote of $25 \mathrm{mM}$ solution $(0.25 \mathrm{mM}$ for CPBA) prepared by dilution of the concentrated solution (or by dissolving a solid) in water was added to the solution containing buffer and supporting electrolyte to have desired concentration. The concentrations were analysed by iodometric titration with sodium thiosulfate [D.A. Skoog, D.M. West, F.J. Holler, Analytical chemistry: an introduction. $6^{\text {th }}$ ed. Saunders College Pub., 1994.] to test for the hydrolysis and spontaneous decomposition [Goodman, J.F.; Robson P.; Wilson E.R. Trans. Faraday Soc. 58 (1962) 1846; Z. Yuan, Y. Ni, A.R.P. van Heiningen, Can. J. Chem. 75 (1997) 42 and refs. therein.] of reactants at different pH. We concluded that these two processes were negligible in the studied solutions at $22^{\circ} \mathrm{C}$ within the time of experiment as the concentrations remained constant.

Procedures. The catalysts were deposited on the electrode surface by syringing a $0.6-1.2 \mu \mathrm{L}$ aliquot of a solution in dimethoxyethane-15\%water mixture ( $\mathrm{Fe}(\mathrm{Ac}), \mathrm{Fe}(\mathrm{NMe}))$ and $\mathrm{THF}$ or $\mathrm{MeOH}(\mathrm{Fe}(\mathrm{tpp}) \mathrm{Cl})$ on a vertically positioned rotating electrode $(300 \mathrm{rpm})$. Catalyst solutions were stored at $-22^{\circ} \mathrm{C}$ when not in use and discarded after 5 days in air to prevent changes in concentration. Turnover numbers (TNs) were determined as described in [R. Boulatov, J.P. Collman, I.M. Shiryaeva, C.J. Sunderland, J. Am. Chem. Soc. 124 (2002) 11923; J.P. Collman, R. Boulatov, C.J. Sunderland, I.M. Shiryaeva, K.E. Berg, J. Am. Chem. Soc. 124 (2002) 10670]. A set of data at different rotation speeds was collected and followed by a potentiostatic run at the desired potential during $1 \mathrm{~min}$ at $200 \mathrm{rpm}$. The electrode was allowed to equilibrate at an open curcuit for $\sim 15 \mathrm{~s}$, and another set of data was collected. The TNs were calculated according to the formula:

$$
T N=\frac{\text { reduced reagent }(\mathrm{mol})}{\text { degraded catalyst }(\mathrm{mol})}=\frac{Q / n F}{A \Gamma\left(1-I_{\text {kin }}^{\prime} / I_{\text {kin }}\right)},
$$

where $Q(\mathrm{C})$ is the charge passed in potentiostatic run, $A\left(\mathrm{~cm}^{2}\right)$ is the electrode area, $\left.\Gamma(\mathrm{mol} \mathrm{cm})^{-2}\right)$ is the surface coverage, and $I_{k i n}$ and $I_{k i n}^{\prime}(\mathrm{A})$ are the kinetic currents determined from the data sets before and after the potentiostatic run, respectively. Other parameters have their usual meaning.

In the ring-disk experiments, the Au ring was not inert to CPBA and PAA, but oxygen could be detected, and

the $i_{\text {ring }}$ values were taken as the difference between the ring current measured in the potential range of the limiting disk currents of $\mathrm{Fe}(\mathrm{III})$ and $\mathrm{Fe}(\mathrm{II})$-catalyzed ROOH reductions.

Equipment. Experiments were carried out in a one-compartment home-made glass cell $(100 \mathrm{~mL})$ with a tightly fitting lid using an edge plane graphite (EPG) rotating disk working electrode (Pine Instruments, $0.195 \mathrm{~cm}^{2}$ ) or a ring-disk electrode with a removable EPG disk and Au ring (Pine Instruments, $\mathrm{N}_{0}=22.5 \%, \mathrm{r}_{10}=$ $5.0 \mathrm{~mm}, \mathrm{r}_{20}=7.5 \mathrm{~mm}$, and $\mathrm{r}_{30}=8.5 \mathrm{~mm}$ ). A BAS CV-50W potentiostat (Bioanalytical Systems) and a Pine AFCBP1 bipotentiostat (Pine Instruments) with an ASR speed controller (Pine Instruments) were used for rotating disk and ring-disk experiments, respectively. The auxiliary electrode was a Pt mesh and the reference electrode was a low flowrate saturated calomel electrode. The EPG disk was cleaned with a 600 grit $\mathrm{SiC}$ paper and sonicated for $1 \mathrm{~min}$ in methanol immediately prior to depositing a catalytic film. The Au ring was cleaned with $0.05-\mathrm{mm} \gamma$-alumina paste for $1 \mathrm{~min}$ followed by sonication in methanol. Experiments were conducted in $\mathrm{N}_{2}$ deaerated solutions at room temperature $\left(22^{\circ} \mathrm{C}\right)$. During measurements $\mathrm{N}_{2}$ was passed above the solution. The electrode rotation speed was changed randomly to eliminate an effect of catalyst degradation. All potentials are given with respect to normal hydrogen electrode (NHE). 

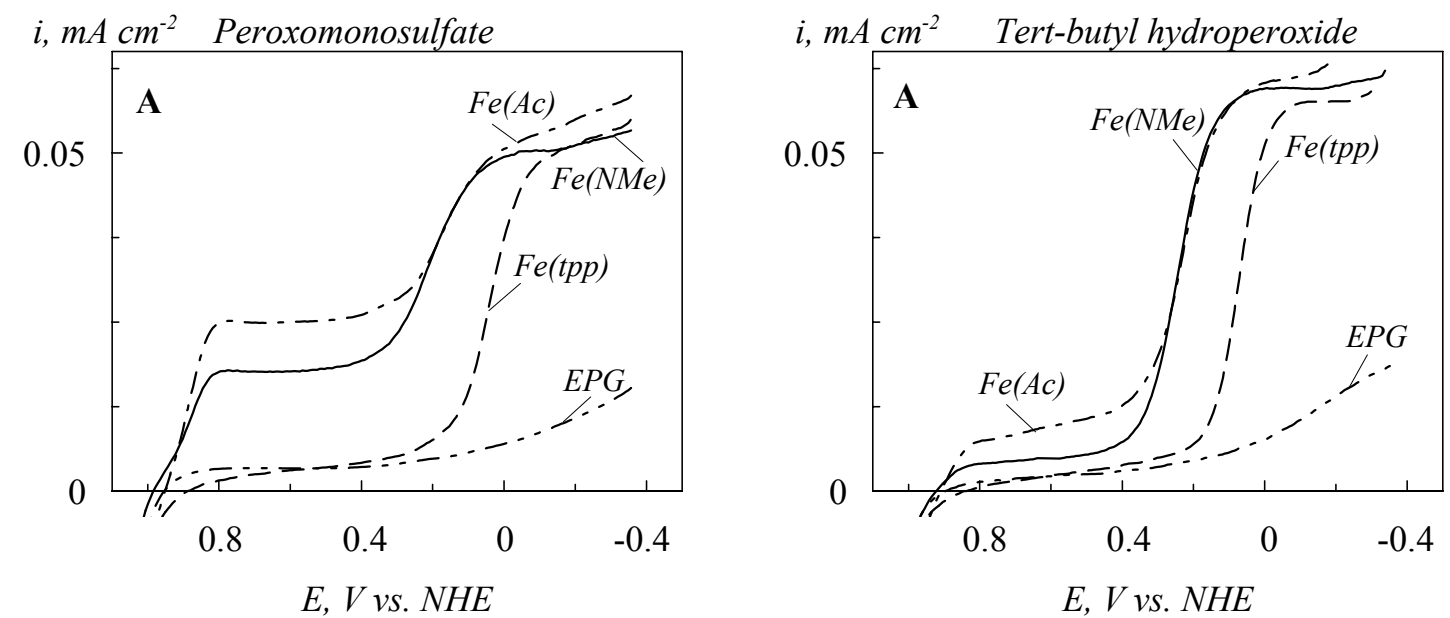

E, $V v s . N H E$

E, Vvs. NHE
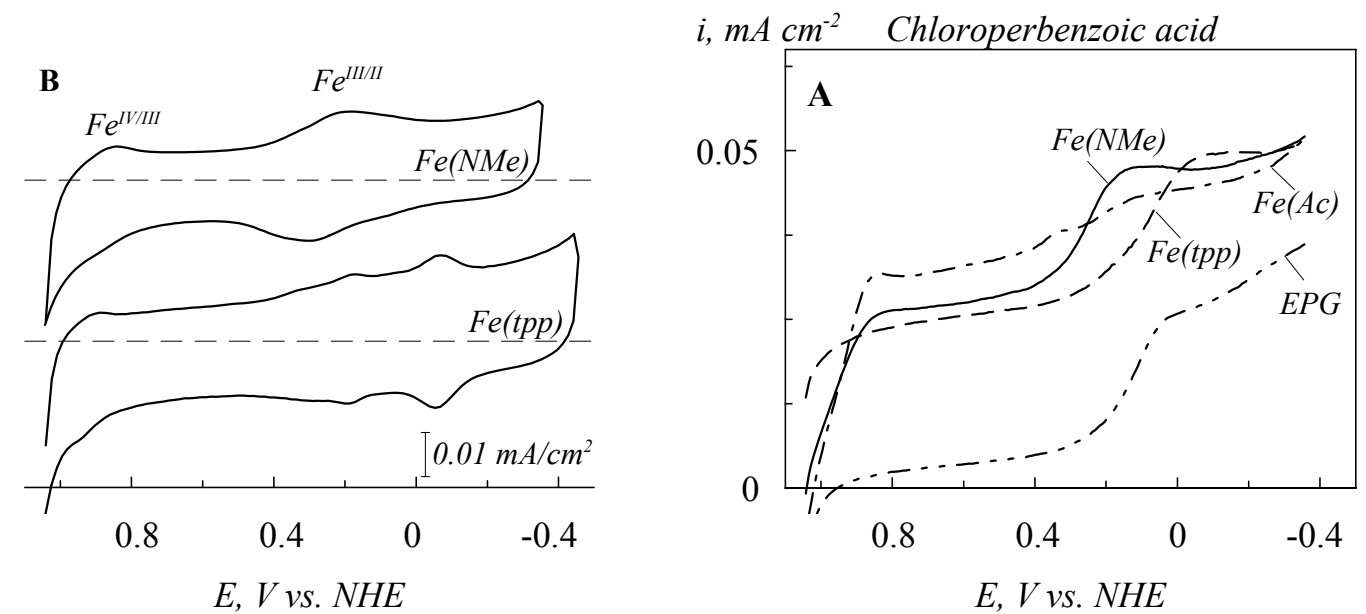

Figure S1. (A) Rotating disk data for reduction of $0.125 \mathrm{mM} \mathrm{KHSO}_{5}, \mathrm{TBHP}$, and CPBA at bare edge plane graphite (EPG) and at iron-porphyrins adsorbed on EPG. Scan rate, $0.02 \mathrm{~V} \mathrm{~s}^{-1}$, rotation speed, $200 \mathrm{rpm}$, surface coverage, $0.75 \mathrm{nmol} \mathrm{cm}{ }^{-2}\left(1.5 \mathrm{nmol} \mathrm{cm}^{-2}\right.$ for CPBA), $0.1 \mathrm{M} \mathrm{KPF}_{6}$, pH 7. (B) Typical cyclic voltammograms of $\mathrm{Fe}(\mathrm{NMe})$ and $\mathrm{Fe}(\mathrm{tpp})$. Scan rate, $0.02 \mathrm{~V} \mathrm{~s}^{-1}$, surface coverage, $0.75 \mathrm{nmol} \mathrm{cm}^{-}$ ${ }^{2}, 0.1 \mathrm{M} \mathrm{KPF}_{6}, \mathrm{pH} 7$. 

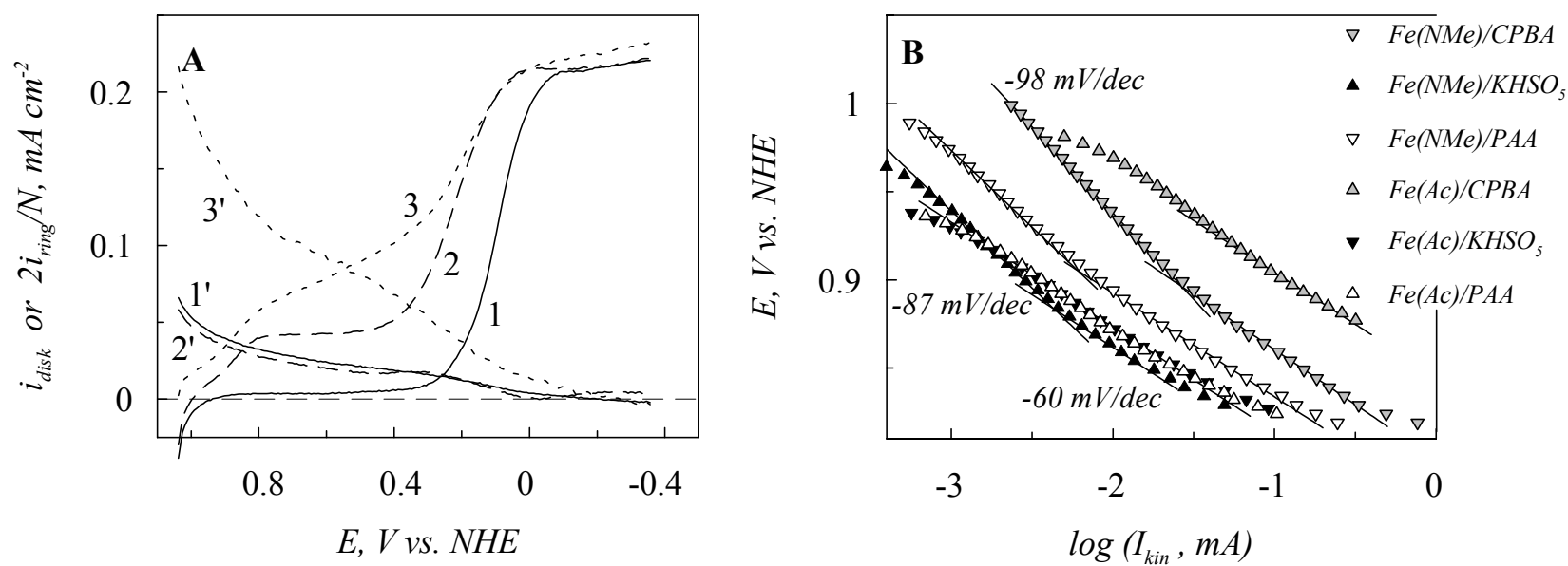

Figure S2. (A) Rotating ring disk electrode data for reduction of $0.25 \mathrm{mM}$ ROOH: $1,1^{\prime}{ }^{-}$ $\mathrm{Fe}(\mathrm{tpp}) / \mathrm{KHSO}_{5}, 2,2^{\prime}-\mathrm{Fe}(\mathrm{NMe}) / \mathrm{KHSO}_{5}$, and 3,3' - $\mathrm{Fe}(\mathrm{NMe}) / \mathrm{PAA}$, where prime (') refers to the ring current. $0.1 \mathrm{M} \mathrm{KNO}_{3}, \mathrm{pH} 7, E_{\text {ring }}=-0.3 \mathrm{~V} v s$. SCE, scan rate of disk potential, $0.02 \mathrm{~V} \mathrm{~s}^{-1}$, rotation speed, $500 \mathrm{rpm}$, catalyst coverage, $1.5 \mathrm{nmol} \mathrm{cm}^{-2}$. (B) Tafel plots for the reduction of $0.125 \mathrm{mM}$ CPBA, PAA and $\mathrm{KHSO}_{5}$ at $\mathrm{Fe}(\mathrm{NMe})$ and $\mathrm{Fe}(\mathrm{Ac})$ in $0.1 \mathrm{M} \mathrm{KNO}_{3}$ at $\mathrm{pH} 7$.

Table S1. Kinetic parameters for the electroreduction of peroxidic reactants at ferric and ferrous forms of $\mathrm{Fe}(\mathrm{tpp}), \mathrm{Fe}(\mathrm{Ac})$ and $\mathrm{Fe}(\mathrm{NMe})$, where $k_{\text {red }}$ and $k_{\text {disp }}$ are the rate constants of reduction and disproportionation, respectively, $\mathrm{TN}$ is the turnover number, $m$ is the order with respect to $\mathrm{ROOH}$, and $p=(\partial E / \partial p H) /\left(\partial E / \partial \log I_{k i n}\right)$ is the order with respect to $\mathrm{H}^{+}$.

\begin{tabular}{|c|c|c|c|c|c|c|c|c|c|c|}
\hline \multirow{3}{*}{ Catalyst } & \multirow{3}{*}{$\mathrm{ROOH}$} & \multirow{3}{*}{$\begin{array}{r}-\frac{\partial E}{\partial p H} \\
\mathrm{mV} \\
\mathrm{Fe}^{\mathrm{II}}\end{array}$} & \multirow{2}{*}{\multicolumn{2}{|c|}{$-\frac{\partial E}{\partial \log I_{k i n}} \frac{\mathrm{mV}}{}$}} & \multirow{3}{*}{$\begin{array}{l}p\left(\mathrm{H}^{+}\right) \\
\mathrm{Fe}^{\mathrm{II}}\end{array}$} & \multirow{3}{*}{$\begin{array}{c}m \\
\mathrm{Fe}^{\mathrm{II}}\end{array}$} & \multirow{3}{*}{$\begin{array}{c}k_{\text {red }}{ }^{\mathrm{a}} \\
\mathrm{M}^{-1} \mathrm{~s}^{-1} \\
\mathrm{Fe}^{\mathrm{III}}\end{array}$} & \multirow{3}{*}{$\begin{array}{c}k_{\text {disp }}{ }^{\mathrm{a}} \\
\mathrm{M}^{-1} \mathrm{~s}^{-1} \\
\mathrm{Fe}^{\mathrm{III}}\end{array}$} & \multirow{3}{*}{$\begin{array}{c}k_{\mathrm{red}}^{\mathrm{b}} \\
\mathrm{M}^{-1} \mathrm{~s}^{-1} \\
\mathrm{Fe}^{\mathrm{II}}\end{array}$} & \multirow{3}{*}{$\begin{array}{l}\mathrm{TN}^{\mathrm{b}} \\
\mathrm{Fe}^{\mathrm{II}}\end{array}$} \\
\hline & & & & & & & & & & \\
\hline & & & $\mathrm{Fe}^{\mathrm{III}}$ & $\mathrm{Fe}^{\mathrm{II}}$ & & & & & & \\
\hline \multirow[t]{4}{*}{$\mathrm{Fe}(\mathrm{tpp})$} & CPBA & $-^{\mathrm{c}}$ & $-{ }^{\mathrm{d}}$ & $-{ }^{\mathrm{c}}$ & $-^{c}$ & $-^{c}$ & $4.5 \mathrm{e} 3$ & $9.0 \mathrm{e} 3$ & $1.2 \mathrm{e} 4$ & 35 \\
\hline & PAA & $0 ; 60 ; 108^{f}$ & $-^{e}$ & 120 & $0 ; 0.5 ; 0.9^{f}$ & 1 & $-{ }^{\mathrm{e}}$ & $4.5 \mathrm{e} 3$ & $1.4 \mathrm{e} 4$ & 21 \\
\hline & $\mathrm{KHSO}_{5}$ & $0 ; 62 ; 110^{f}$ & $-{ }^{\mathrm{e}}$ & 120 & $0 ; 0.5 ; 0.9^{\mathrm{f}}$ & 1 & $-{ }^{\mathrm{e}}$ & 413 & $1.3 \mathrm{e} 4$ & 69 \\
\hline & TBHP & $0 ; 56^{f}$ & $-{ }^{\mathrm{e}}$ & 120 & $0 ; 0.5^{\mathrm{f}}$ & 1 & $-{ }^{\mathrm{e}}$ & 227 & $1.6 \mathrm{e} 4$ & 37 \\
\hline \multirow[t]{4}{*}{$\mathrm{Fe}(\mathrm{Ac})$} & CPBA & $-{ }^{\mathrm{c}}$ & 60 & $-{ }^{\mathrm{c}}$ & $-{ }^{c}$ & $-^{\mathrm{c}}$ & $6.0 \mathrm{e} 3$ & $6.2 \mathrm{e} 3$ & $2.5 \mathrm{e} 4$ & 48 \\
\hline & PAA & $-{ }^{\mathrm{c}}$ & 60 & $-{ }^{\mathrm{c}}$ & $-^{\mathrm{c}}$ & $-{ }^{c}$ & $2.0 \mathrm{e} 3$ & $2.6 \mathrm{e} 3$ & $2.6 \mathrm{e} 4$ & 61 \\
\hline & $\mathrm{KHSO}_{5}$ & $-{ }^{\mathrm{c}}$ & 60 & $-{ }^{\mathrm{c}}$ & $-^{\mathrm{c}}$ & $-{ }^{\mathrm{c}}$ & $1.8 \mathrm{e} 3$ & 842 & $2.8 \mathrm{e} 4$ & 125 \\
\hline & TBHP & $0 ; 59^{\mathrm{f}}$ & $-{ }^{\mathrm{e}}$ & 120 & $0 ; 0.5^{\mathrm{f}}$ & 1 & 234 & 404 & $2.7 \mathrm{e} 4$ & 87 \\
\hline \multirow[t]{4}{*}{$\mathrm{Fe}(\mathrm{NMe})$} & CPBA & $-{ }^{\mathrm{c}}$ & 60 & $-{ }^{c}$ & $-{ }^{c}$ & $-{ }^{c}$ & $5.4 \mathrm{e} 3$ & $5.2 \mathrm{e} 3$ & $2.6 \mathrm{e} 4$ & 33 \\
\hline & PAA & $-{ }^{\mathrm{c}}$ & 60 & $-{ }^{c}$ & $-{ }^{\mathrm{c}}$ & $-{ }^{\mathrm{c}}$ & $1.3 \mathrm{e} 3$ & $1.8 \mathrm{e} 3$ & $2.4 \mathrm{e} 4$ & 68 \\
\hline & $\mathrm{KHSO}_{5}$ & $-{ }^{\mathrm{c}}$ & 60 & $-{ }^{\mathrm{c}}$ & $-^{\mathrm{c}}$ & $-{ }^{c}$ & 950 & 477 & $2.6 \mathrm{e} 4$ & 70 \\
\hline & TBHP & $0 ; 57^{\mathrm{f}}$ & $-^{\mathrm{e}}$ & 120 & $0 ; 0.5^{\mathrm{f}}$ & 1 & 227 & 311 & $2.3 \mathrm{e} 4$ & 41 \\
\hline
\end{tabular}

$\mathrm{a}-\mathrm{E}=0.70 \mathrm{~V} v s . \mathrm{NHE}, \mathrm{pH} 7, \Gamma=1.5 \mathrm{nmol} \mathrm{cm}^{-2}, \mathrm{c}=0.25 \mathrm{mM}$, and $\omega=500 \mathrm{rpm}$;

${ }^{\mathrm{b}}-\mathrm{E}=-0.05 \mathrm{~V}(\mathrm{Fe}(\mathrm{NMe})),-0.10 \mathrm{~V}(\mathrm{Fe}(\mathrm{Ac}))$ and $-0.15 \mathrm{~V}(\mathrm{Fe}(\operatorname{tpp})) v s . \mathrm{NHE}, \mathrm{pH} 7, \Gamma=0.5 \mathrm{nmol} \mathrm{cm}{ }^{-2}, \mathrm{c}=0.125 \mathrm{mM}$; c, d, e - not determined because of: ${ }^{\mathrm{c}}$ - overlapping of the studied process with residual catalysis by $\mathrm{Fe}^{\mathrm{III}}$; $^{\mathrm{d}}-$ overlapping of the studied process with water oxidation; ${ }^{\mathrm{e}}$ - no (or low) catalytic activity;

${ }^{\mathrm{f}}$ - the $\mathrm{pH}$ dependence of potential presents three regions (Fig.S5): zero slope is observed at $\mathrm{pH}<\mathrm{pKa}\left(\mathrm{Fe}{ }^{\mathrm{III}} \mathrm{H}_{2} \mathrm{O}\right)$, the slope of $-60 \mathrm{mV} / \mathrm{pH}-$ at $\mathrm{pKa}\left(\mathrm{Fe}^{\mathrm{III}} \mathrm{H}_{2} \mathrm{O}\right)<\mathrm{pH}<\mathrm{pKa}(\mathrm{ROOH})$, and the slope of $-110 \mathrm{mV} / \mathrm{pH}-$ at $\mathrm{pH}>\mathrm{pKa}(\mathrm{ROOH})$; the chemical orders in protons are given in the same sequence as the slope values. 

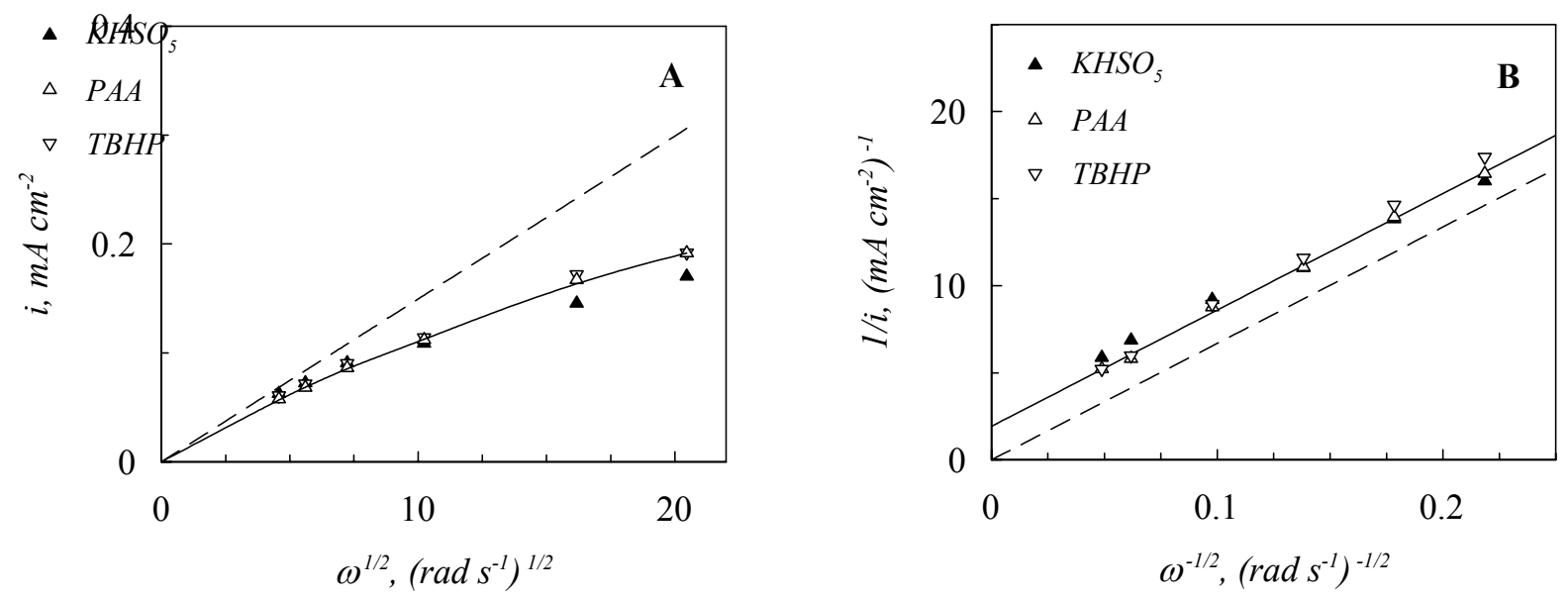

Figure S3. Typical Levich (A) and Koutecky-Levich (B) plots of limiting currents of

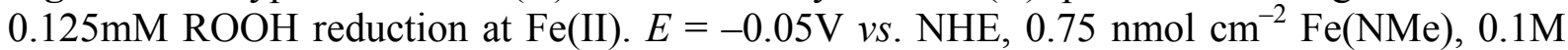
$\mathrm{KPF}_{6}, \mathrm{pH}$ 7. The dashed lines represent the responses calculated for the diffusion limited twoelectron reduction.
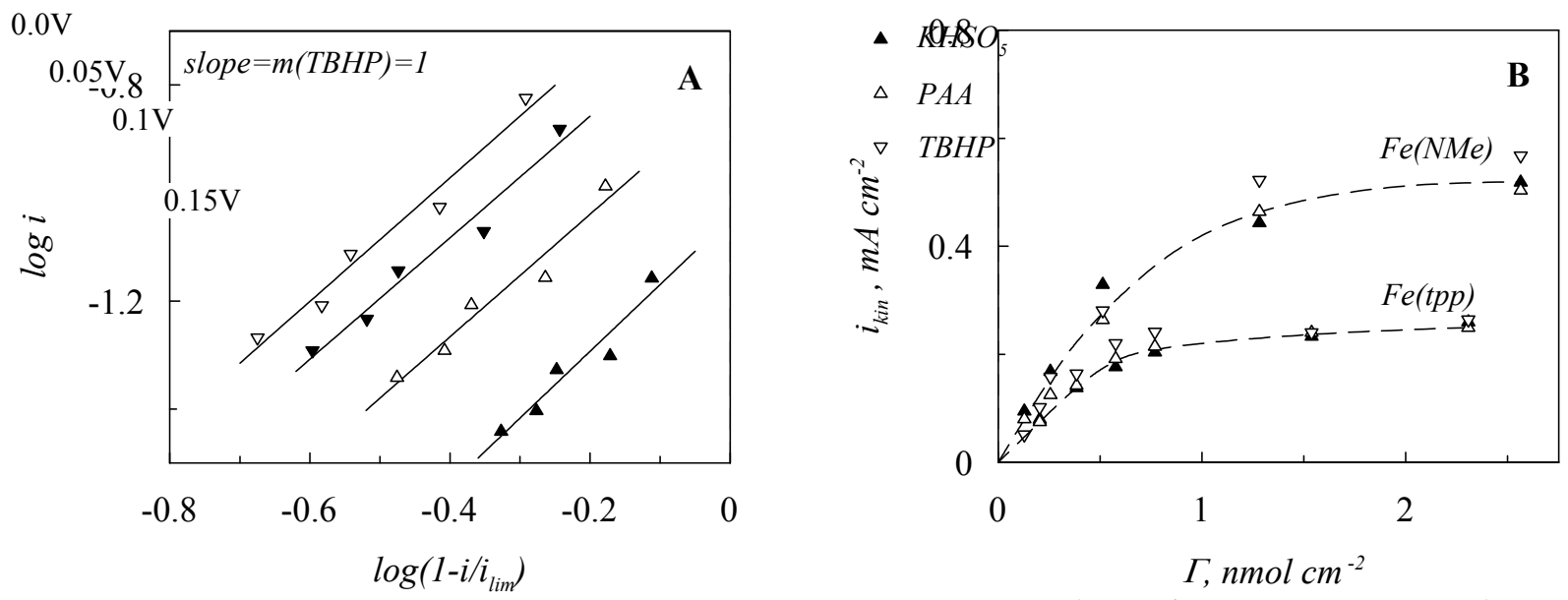

(according to geometric area)

Figure S4. (A) Plot for determination of the reaction order with respect to TBHP. $0.75 \mathrm{nmol}$ $\mathrm{cm}^{-2} \mathrm{Fe}(\mathrm{NMe}), c=0.125 \mathrm{mM}, 0.1 \mathrm{M} \mathrm{KPF}, \mathrm{pH}$ 7. The plots created for $\mathrm{Fe}(\mathrm{tpp}) / \mathrm{TBHP}$, $\mathrm{KHSO}_{5}, \mathrm{PAA}$, and $\mathrm{Fe}(\mathrm{Ac}) / \mathrm{TBHP}$ also presented parallel lines for different potentials with the slope equal to 1. (B) Kinetic current density (from Koutecky-Levich plots) as a function of the catalyst surface coverage. $c=0.125 \mathrm{mM}, 0.1 \mathrm{M} \mathrm{KPF}_{6}, \mathrm{pH} 7$. 

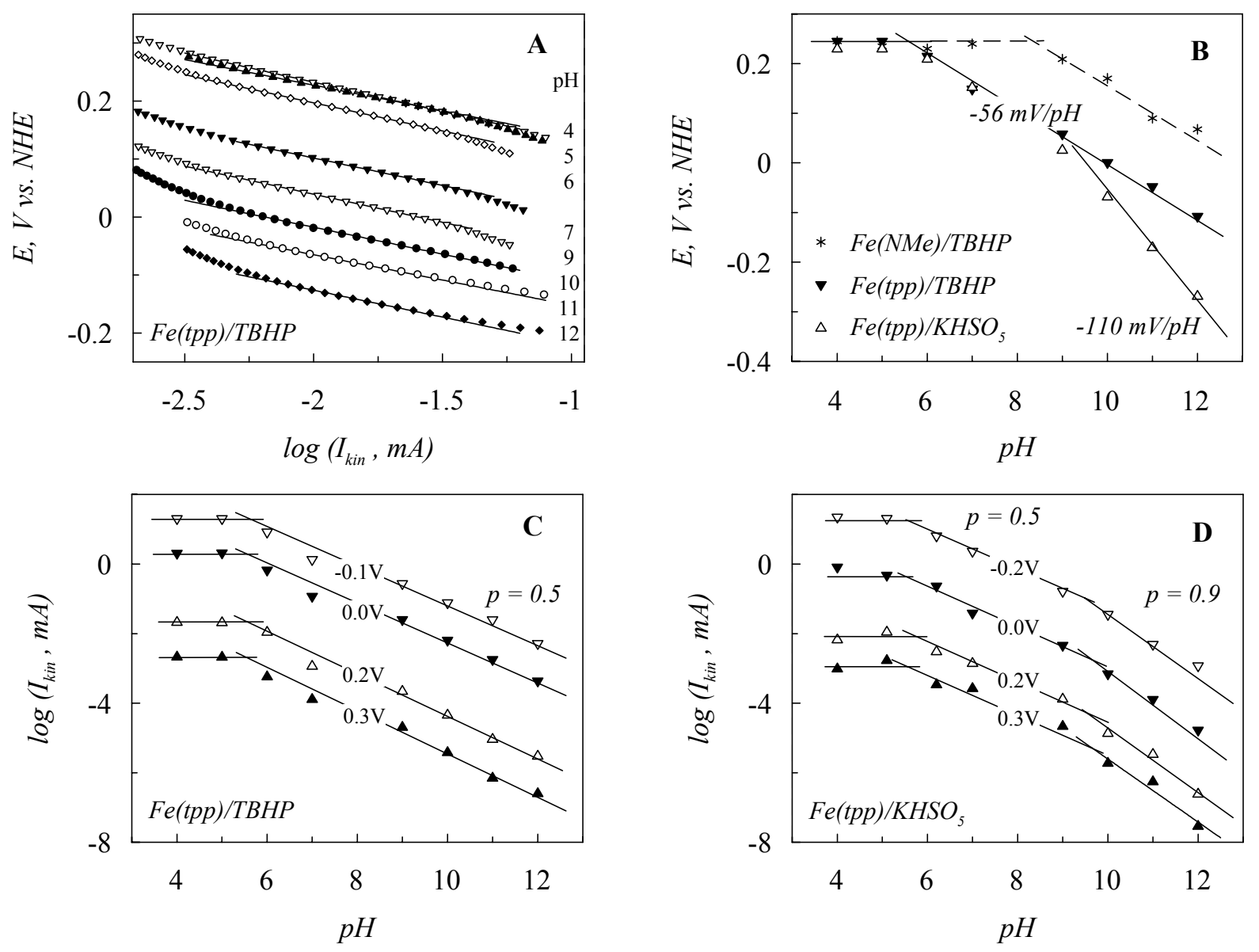

Figure S5. (A) Tafel plots for the reduction of $0.125 \mathrm{mM}$ TBHP at $\mathrm{Fe}(\mathrm{tpp})$ in $0.1 \mathrm{M} \mathrm{KNO}$ solutions of different $\mathrm{pH}$. (B) Plot of potential at constant current $v s$. $\mathrm{pH}$ for the reduction of TBHP and $\mathrm{KHSO}_{5}$ at $\mathrm{Fe}(\mathrm{tpp})$, and TBHP at $\mathrm{Fe}(\mathrm{NMe})$. The currents were taken from linear parts of the corresponding Tafel plots. (C) Effect of $\mathrm{pH}$ on the currents at constant potential for TBHP reduction at Fe(tpp) derived from Tafel plots (A). (D) Effect of $\mathrm{pH}$ on the currents at constant potential for $0.125 \mathrm{mM} \mathrm{KHSO}_{5}$ reduction at $\mathrm{Fe}(\mathrm{tpp})$ derived from corresponding Tafel plots. The plot for $\mathrm{Fe}(\mathrm{tpp}) / \mathrm{PAA}$ was similar to that presented for $\mathrm{Fe}(\mathrm{tpp}) / \mathrm{KHSO}_{5}$. 
APPENDIX. Koutecky-Levich eq. corrected for a parallel reaction.

$$
\begin{aligned}
& \stackrel{i_{\mathrm{ROOH}}}{\longrightarrow} \mathrm{ROOH} \stackrel{i_{1}}{\longrightarrow} \mathrm{ROH}+\mathrm{H}_{2} \mathrm{O} \\
& \stackrel{i_{2}}{\longrightarrow} \mathrm{ROH}+1 / 2 \mathrm{O}_{2} \stackrel{i_{\mathrm{O}_{2}}}{\longrightarrow}
\end{aligned}
$$

$\rightarrow \quad \mathrm{ROOH}$ diffusion from bulk

$\mathrm{ROOH}+2 e^{-}+2 \mathrm{H}^{+} \rightarrow \mathrm{ROH}+\mathrm{H}_{2} \mathrm{O}$

$\mathrm{ROOH} \rightarrow \mathrm{ROH}+1 / 2 \mathrm{O}_{2}$

$\leftarrow \mathrm{O}_{2}$ diffusion into bulk

$\mathrm{O}_{2}+2 e^{-}+2 \mathrm{H}^{+} \rightarrow \mathrm{H}_{2} \mathrm{O}_{2}$ $i_{\text {ROOH }}$

$i_{1}, k_{1}$

$i_{2}, k_{2}$

$i_{\mathrm{O}_{2}}$

$i_{\text {ring }}$

1. Assuming that all reactions are first-order, the current density will be $i_{i}=n F k_{i} \Gamma^{s} c_{j}^{\text {surf }}$

$i_{1}=2 F k_{1} \Gamma^{s} c_{R O O H}^{\text {surf }} ; i_{2}=2 F k_{2} \Gamma^{s} c_{R O O H}^{\text {surf }} *$

2. The diffusion rates for $\mathrm{O}_{2}$ and $\mathrm{ROOH}: *$

$i_{\mathrm{ROOH}}=2 \mathrm{~F} \kappa_{\mathrm{ROOH}}\left(c_{\mathrm{ROOH}}^{\text {bulk }}-c_{\mathrm{ROOH}}^{\text {surf }}\right)$
$i_{\mathrm{O}_{2}}=2 \mathrm{~F} \kappa_{\mathrm{O}_{2}} c_{\mathrm{O}_{2}}^{\text {surf }}, c_{\mathrm{O}_{2}}^{\text {bulk }}=0$, , where diffusion constant $\kappa_{j}=\gamma_{j} \sqrt{\omega}, \gamma_{j}=0.62 D_{j}^{2 / 3} v^{-1 / 6}$.

* catalytic decomposition is arbitrarily assumed to involve $2 e^{-}$per ROOH molecule;

* rates for non-electrochemical steps are expressed in electrochemical units.

3. The currents measured at the disk and ring electrodes:

$i_{\text {disk }}=i_{1}$,

$i_{\text {ring }}=N \times i_{O_{2}}$, where $N$ - collection efficiency.

4. The conditions for steady-state surface concentrations can be represented as equalities of the overall uptake and loss rates: for $\mathrm{ROOH}: \quad i_{\mathrm{ROOH}}=i_{1}+i_{2}$

(A.4)

for $\mathrm{O}_{2}: \quad 1 / 2 i_{2}=i_{O_{2}}$

5. Using Eqs. (A.2-A.4), the surface concentration of $\mathrm{ROOH}$ can be represented with measurable quantities:

$c_{R O O H}^{\text {surf }}=c_{R O O H}^{\text {bulk }}-\frac{i_{R O O H}}{2 F \kappa_{R O O H}}=c_{R O O H}^{\text {bulk }}-\frac{i_{1}+2 i_{O_{2}}}{2 F \kappa_{R O O H}}=c_{R O O H}^{b u l k}\left(1-\frac{i_{\text {disk }}+2 i_{\text {ring }} / N}{i_{\text {lim }}}\right)$,

$i_{\text {lim }}=2 F \kappa_{R O O H} c_{R O O H}^{\text {bulk }}$ is maximum diffusion current density.

6. Since the surface concentration can be found, Eq.(A.5), the rate constants can be calculated:

$$
\begin{aligned}
& i_{\text {disk }}=i_{1}=2 F k_{1} \Gamma^{s} c_{R O O H}^{\text {surf }}=2 F k_{1} \Gamma^{s} c_{R O O H}^{\text {bulk }}\left(1-\frac{i_{\text {disk }}+2 i_{\text {ring }} / N}{i_{\text {lim }}}\right), \\
& 2 i_{\text {ring }} / N=i_{2}=2 F k_{2} \Gamma^{s} c_{R O O H}^{\text {surf }}=2 F k_{2} \Gamma^{s} c_{R O O H}^{\text {bulk }}\left(1-\frac{i_{\text {disk }}+2 i_{\text {ring }} / N}{i_{\text {lim }}}\right) .
\end{aligned}
$$

7. Rearrangement of Eqs. (A.6) gives analoques of the Koutecky-Levich equation corrected for a parallel reaction:

$$
\begin{aligned}
& \frac{1}{i_{\text {disk }}}\left(1-\frac{2 i_{\text {ring }} / N}{i_{\text {lim }}}\right)=\frac{1}{i_{1, k i n}}+\frac{1}{i_{\text {lim }}} ; \\
& \frac{1}{2 i_{\text {ring }} / N}\left(1-\frac{i_{\text {disk }}}{i_{\text {lim }}}\right)=\frac{1}{i_{2, \text { kin }}}+\frac{1}{i_{\text {lim }}},
\end{aligned}
$$

where $i_{i, k i n}=2 F k_{i} \Gamma^{s} c_{R O O H}^{b u l k}$ is the kinetic current of the $i$-th reaction. 